\title{
PENGARUH LAMA FERMENTASI DAN PENGEPRESAN BERULANG TERHADAP MUTU KAKAO BUBUK
}

\author{
The Effect of Fermentation Time and Repeated Pressing on \\ Cocoa Powder Quality
}

\author{
Melia Ariyanti, Sitti Ramlah, dan Medan Yumas \\ Balai Besar Industri Hasil Perkebunan \\ Jl. Prof. Dr. H. Abdurahman Basalamah No.28 Makassar \\ email: melia.bbihp@gmail.com
}

\begin{abstract}
This study aims to determine the effect of fermentation time and repeated pressing on the cocoa powder quality produced according to SNI 3747: 2009. The research method used experiment method with 4 treatments ie fermentation length 5 and 6 days and repetition of 3 and 4 presses, and then the results being analized descriptively. The cocoa beans used are from Belopa, Luwu Regency of South Sulawesi. Parameters analyzed in accordance with SNI 3747: 2009 cocoa powder include state, smoothness, moisture content, fat content, metal contamination, and microbial contamination. The results showed that in general the quality of fermented cocoa powder of the research results have met the quality standards of Cocoa Powder SNI 3747: 2009. Water content of cocoa powder according to the maximum standard of 5.0\% that is between 3,69-4,3\%. More pressing treatment can reduce the fat content contained in cocoa powder. The resulting fat content ranged from 11,32 - 14,82 \%.
\end{abstract}

Keywords: cocoa powder, fermentation time, quality, pressing, SNI 3747:2009

\begin{abstract}
Abstrak Penelitian ini bertujuan untuk mengetahui pengaruh lama fermentasi dan pengepresan berulang terhadap mutu kakao bubuk yang dihasilkan sesuai SNI 3747: 2009. Metode penelitian menggunakan metode eksperimen dengan 4 perlakuan yaitu lama fermentasi 5 dan 6 hari serta pengulangan pengepresan 3 dan 4 kali press, kemudian dianalisis secara deskriptif. Biji kakao yang digunakan berasal dari Belopa, Luwu, Sulawesi Selatan. Parameter yang dianalisa sesuai dengan SNI 3747: 2009 kakao bubuk meliputi keadaan, kehalusan, kadar air, kadar lemak, cemaran logam, dan cemaran mikroba. Hasil penelitian menunjukkan bahwa secara umum mutu kakao bubuk fermentasi hasil penelitian sudah memenuhi standar mutu kakao bubuk SNI 3747: 2009. Kadar air kakao bubuk sesuai standar maksimum 5,0 \% yaitu antara 3,69-4,3\%. Semakin banyak perlakuan pengepresan dapat mengurangi kadar lemak yang terdapat dalam kakao bubuk. Kadar lemak yang dihasilkan berkisar antara 11,32-14,82\%.
\end{abstract}

Kata kunci: kakao bubuk, lama fermentasi, mutu, pengepresan, SNI 3747: 2009

\section{PENDAHULUAN}

Kakao bubuk merupakan produk yang diperoleh dari bungkil kakao yang dihaluskan menjadi bubuk. Kakao bubuk di Indonesia banyak dimanfaatkan oleh industri makanan dan minuman sebagai campuran dalam produk olahan pangan berbasis cokelat. Permasalahan yang ada dalam industri adalah kakao bubuk yang masih tinggi kadar lemaknya, serta kualitas warna bubuk yang belum seragam dibandingkan kakao bubuk impor (Mulato et al., 2005).

Proses pengolahan biji kakao menjadi kakao bubuk melalui proses pengempaan/ press pasta. Sebagian besar lemak kakao (cocoa butter) yang ada di dalam pasta cokelat (chocolate liquor/ chocolate mass) harus dipisahkan. Proses pengeluaran lemak ini dilakukan dengan mengepress (hidraulik atau mekanis) untuk menghasilkan bungkil (press cake), selanjutnya dihaluskan dan diayak untuk memperoleh ukuran partikel bubuk yang seragam. Kadar lemak di dalam kakao bubuk berkisar antara $10-12 \%$ untuk low fat cocoa butter. Kakao bubuk berkadar lemak lebih tinggi biasanya memiliki warna lebih gelap dengan flavor yang lebih ringan (Abraham, 1982).

Standar Nasional Indonesia (SNI) 3747: 2009 menyebutkan bahwa kakao bubuk mempunyai persyaratan tingkat 
kehalusan 200 mesh. Persyaratan tersebut hanya bisa dipenuhi oleh industri besar, sedangkan Industri Kecil Menengah (IKM) sulit memperoleh ayakan dengan ukuran 200 mesh, karena yang umum beredar di pasaran hanya ukuran 120 mesh. Oleh karena itu kakao bubuk yang dihasilkan masih kasar. Kakao bubuk dengan ukuran 120 mesh apabila dibuat menjadi minuman cokelat, akan terasa kasar dan banyak tersisa endapan karena tidak bisa seluruhnya terdispersi dalam air, meskipun minuman tersebut disiram dengan air panas.

Kakao bubuk diolah dari biji kakao yang telah difermentasi. Melalui proses fermentasi kadarlemakyang dihasilkanmeningkatkarena tekstur biji kakao menjadi berpori sehingga lemak lebih mudah keluar, sedangkan biji yang tidak difermentasi mempunyai tekstur biji pejal yang menyebabkan lemak lebih sulit terekstrak keluar. Untuk itu perlu ada penelitian yang bertujuan untuk mengetahui pengaruh lama fermentasi dan pengepresan berulang terhadap mutu kakao bubuk yang dihasilkan sesuai SNI 3747: 2009.

\section{METODOLOGI}

Penelitian dilaksanakan di Gapoktan Resoe Pammase, Kabupaten Luwu dan pengujian dilakukan di Laboratorium Pengujian Balai Besar Industri Hasil Perkebunan Makassar pada bulan Juni sampai Agustus 2016.

\section{Bahan dan Alat}

Bahan baku penelitian yaitu biji kakao fermentasi dari kebun petani di Kec. Larompong, Belopa Kabupaten Luwu, Sulawesi Selatan.

Alat pendukung penelitian berupa: alat-alat proses pengolahan kakao yaitu alat penyangrai biji kakao, winnower (pemisah kulit biji), pemasta kasar kapasitas $5 \mathrm{~kg}$, pemasta halus/ ball mill, alat press lemak kakao, blender Madato, ayakan stainless steel, timbangan kasar Ohaus. Alat-alat untuk pengujian antara lain: neraca analitik Explorer Pro, oven Memmert U.30, AAS ( Atomic
Absorption Spectrophotometer) Perkin Elmer dan alat gelas lainnya untuk analisis.

\section{Metode Penelitian}

Menggunakan metode eksperimen dengan 4 perlakuan yaitu lama fermentasi 5 dan 6 hari karena keragaan fisik dan kimia biji kakao terbaik diperoleh dari hasil fermentasi sempurna selama 5-6 hari (Towaha dkk, 2012) serta pengulangan pengepresan 3 dan 4 kali press yang menghasilkan kadar lemak yang memenuhi standar mutu SNI 3747:2009 (Ariyanti, 2017). Tahapan pengolahan biji kakao menjadi kakao bubuk dapat dilihat pada Gambar 1. Proses pengolahan biji kakao fermentasi yang sudah dikeringkan menjadi kakao bubuk dimulai dengan penyortiran untuk memisahkan kotoran dari biji kakao, kemudian masuk ke penyangraian (roasting), pemisahan kulit biji (winnowing), pemastaan sehingga diperoleh pasta halus (cocoa liquor). Pasta cokelat kemudian dipress menggunakan alat press lemak kakao. Pengepresan dilakukan pada kondisi suhu $50^{\circ} \mathrm{C}$, tekanan $60 \mathrm{MPa}\left(\mathrm{kgf} / \mathrm{cm}^{2}\right)$ selama 10 menit. Pengepresan ini dilakukan berulang sebanyak 3 dan 4 kali. Pengulangan perlakuan press dimaksudkan untuk mengoptimalkan kinerja alat press sehingga proses pengempaan dapat mengeluarkan lebih banyak lagi lemak kakao. Selanjutnya kakao bubuk dilakukan pengujian mengacu pada SNI 3747:2009 untuk parameter kehalusan lolos ayakan 200 mesh, kadar air dan kadar lemak menggunakan metode gravimetri (AOAC, 1995), cemaran logam dan cemaran mikroba. Setiap pengujian dilakukan 2 kali ulangan. 


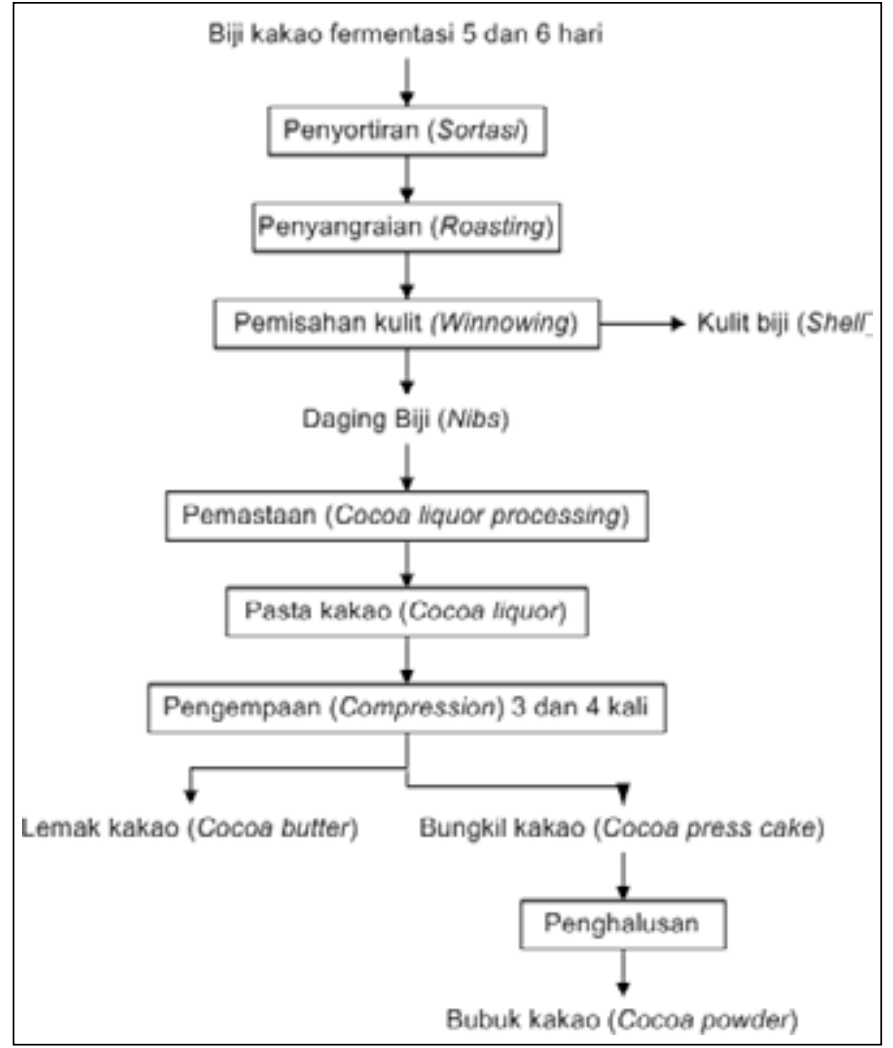

Gambar 1. Tahapan Pengolahan Biji Kakao Menjadi Kakao bubuk

\section{Analisis Data}

Metode analisis data yang digunakan adalah metode analisis deskriptif, yaitu analisis mendasar untuk menggambarkan keadaan data secara umum dan membandingkan dengan standar yang ada. Dalam penelitian ini data yang dianalisis adalah data hasil pengujian sampel kakao bubuk yang dibandingkan dengan standar mutu kakao bubuk sesuai SNI 3747: 2009.

\section{HASIL DAN PEMBAHASAN}

\section{Kehalusan}

Hasil analisis kehalusan (lolos ayakan mesh 200) kakao bubuk hasil penelitian dapat dilihat pada Gambar 2. Hasil uji kehalusan menunjukkan bahwa semua kakao bubuk yang dihasilkan lolos ayakan mesh 200 melebihi $99 \%$ dan telah memenuhi standar mutu SNI. Hasil ini disebabkan proses pengepresan dilakukan secara berulang sehingga lemak yang tertinggal dalam kakao bubuk tersisa sedikit sehingga bubuk menjadi lebih halus dan lebih mudah lolos ayakan.

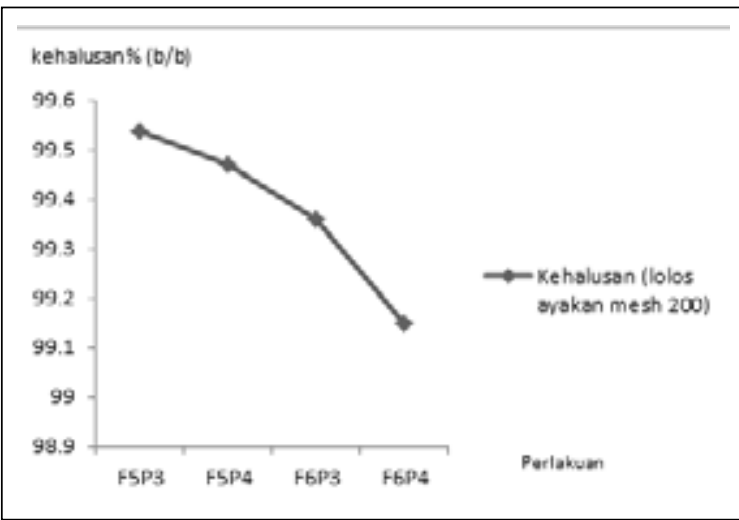

Gambar 2. Grafik hasil analisis kehalusan kakao bubuk

Keterangan:

F5P3 : Bubuk kakao fermentasi 5 hari dipress sebanyak 3 kali

F5P4 : Bubuk kakao fermentasi 5 hari dipress sebanyak 4 kali

F6P3 : Bubuk kakao fermentasi 6 hari dipress sebanyak 3 kali

F6P4 : Bubuk kakao fermentasi 6 hari dipress sebanyak 4 kali 


\section{Kadar Air}

Hasil analisis kakao bubuk yang diperoleh (Gambar 3) masih memenuhi syarat mutu SNI bubuk yaitu maksimal 5,0\%. Kadar air kakao bubuk berada pada rentang 3,69$4,3 \%$. Semakin banyak proses pengepresan pasta kakao menghasilkan kadar air bubuk yang lebih tinggi. Hal ini disebabkan suhu dan lama pengulangan pengepresan pada suhu $50^{\circ} \mathrm{C}$ membuat bungkil yang dihaluskan menjadi bubuk lebih lama proses pengeringannya, sehingga bubuk kakao bersifat lebih higroskopis (mudah mengikat air dari udara) dan mengakibatkan kenaikan kadar air kakao bubuk. Semakin lama fermentasi dilakukan maka kadar air kakao bubuk semakin meningkat. Hal ini disebabkan karena aktivitas mikroba dan enzim dalam mendegradasi jaringan komplek (pulp) menjadi senyawa organik sederhana lebih aktif sehingga pulp hancur akibatnya pori - pori menjadi terbuka yang memudahkan air masuk selama fermentasi (Nasution, et al., 1985). Sementara itu, menurut Mulato dan Widyotomo (2003), waktu fermentasi adalah salah satu faktor penting penyebab meningkatnya kadar air sehingga dengan meningkatnya waktu fermentasi maka kadar air dalam biji kakao akan meningkat pula.

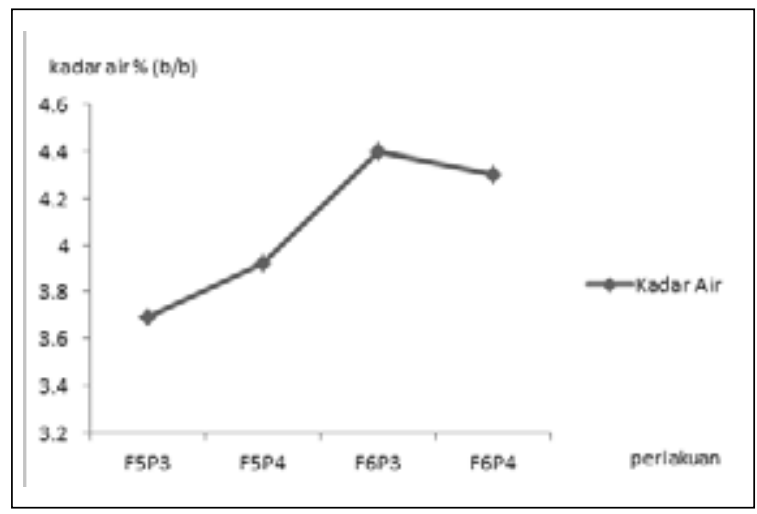

Gambar 3. Grafik hasil analisis kadar air kakao bubuk

\section{Kadar Lemak}

Lemak kakao atau cocoa butter merupakan lemak yang diperoleh dari pasta cokelat (liquor) melalui proses pengepresan atau pengempaan. Semakin banyak perlakuan pengepresan akan mengurangi kadar lemak yang terdapat dalam kakao bubuk. Hal ini disebabkan semakin banyak pengulangan pengepresan maka lemak kakao yang dikeluarkan lebih banyak akibat tekanan dan suhu alat press. Dengan proses pemanasan, lemak menjadi cair dan viskositas lemak akan berkurang sehingga lebih memudahkan lemak keluar mengalir dari matriks sel-sel kakao. Hal ini sesuai dengan penelitian Venter et al. (2007), bahwa suhu mempengaruhi perolehan lemak pada proses pengepresan lemak kakao. Menurut Mulato et al (2005), lemak kakao akan relatif mudah dikempa pada suhu $40-45^{\circ} \mathrm{C}$, kadar air $<4 \%$ dan ukuran partikel $<75 \mathrm{m \mu}$. Suhu pengepresan dilakukan pada suhu $50^{\circ} \mathrm{C}$, dibawah suhu $70^{\circ} \mathrm{C}$ karena dapat menyebabkan organoleptik warna dan aroma kakao menurun drastis serta mengurangi peluang terjadinya peningkatan kadar asam lemak bebas.

Hasil analisis kakao bubuk dapat dilihat bahwa secara umum kakao bubuk hasil penelitian sudah memenuhi standar SNI kakao bubuk 3747:2009. Grafik kadar lemak yang diperoleh (Gambar 4) menunjukkan kadar lemak kakao bubuk $(11,32-14,82 \%)$ sudah memenuhi syarat mutu SNI yaitu minimal10\%. Dalam penelitian ini untuk satu kali pengepresan pasta kakao sebanyak 3 $\mathrm{kg}$, sedangkan kapasitas alat press lemak kakao untuk satu kali press maksimal $5 \mathrm{~kg}$.

Semakin lama waktu fermentasi ternyata kandungan lemak yang tersisa dalam kakao bubuk hasil pengepresan semakin sedikit dan semakin pendek waktu fermentasi biji kakao akan memiliki sifat yang lebih keras dan sulit untuk dilumatkan. Diduga biji kakao dengan waktu fermentasi pendek memiliki nisbah antara jumlah partikel non lemak dan senyawa lemaknya masih relatif besar. Makin lama waktu fermentasi, jumlah senyawa organik yang terurai semakin banyak. Senyawa yang telah terurai akan keluar dan meninggalkan rongga-rongga kosong dalam jaringan keping biji kakao (Mulato et al, 2008). Makin lama waktu fermentasi, jumlah rongga akan semakin banyak sehingga biji kakao yang terfermentasi selama 6 hari akan 
memiliki sifat yang lebih rapuh dan lemak akan lebih mudah terekstraksi dibandingkan biji kakao dengan waktu fermentasi 5 hari. Hasil ini berbanding lurus dengan tingkat kehalusan kakao bubuk yang dihasilkan.

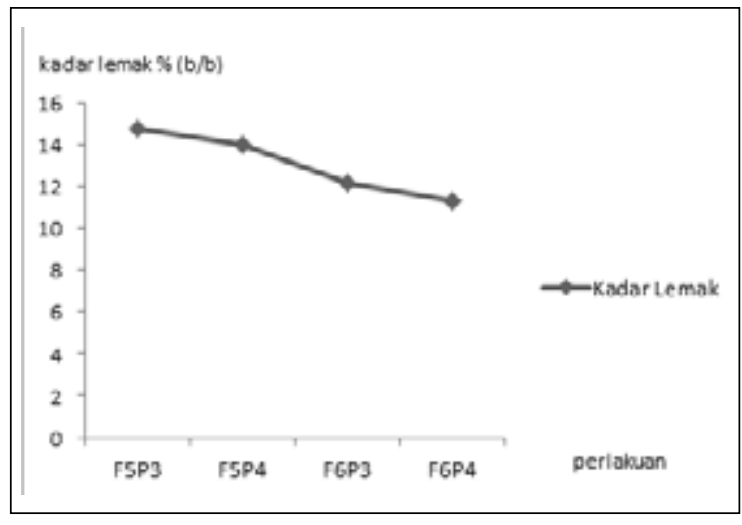

Gambar 4. Grafik hasil analisis kadar lemak kakao bubuk

Hasil penelitian ini sejalan dengan Ginting (2011), bahwa semakin lama proses fermentasi biji kakao maka kadar lemak kakao bubuk yang dihasilkan semakin menurun yang disebabkan karena aktivitas mikroba semakin aktif mendegradasi senyawa komplek menjadi senyawa sederhana sehingga memudahkan pengeluaran lemak dari biji kakao pada proses pengepresan. Hal ini berakibat pada kadar lemak kakao bubuk semakin berkurang atau menurun. Kadar lemak yang rendah dipengaruhi oleh komponen kadar air yang terlalu tinggi. Menurut Yusianto et al (1997), kadar lemak biji kakao tanpa fermentasi lebih rendah 0,07$5,69 \%$ daripada biji kakao yang difermentasi tergantung pada waktu fermentasinya. Fermentasi dapat menurunkan kadar bahan bukan lemak sehingga secara relatif kadar lemak meningkat.

Pengulangan pengepresan sebanyak 4 kali lebih efektif mengeluarkan lemak kakao dibanding dengan pengepresan sebanyak 3 kali. Proses pengepresan yang dilakukan secara bertahap dan terus menerus menyebabkan ukuran partikel keping biji dan pasta yang semula kasar akan mengecil dan mendekati ukuran sel-sel daging biji tempat senyawa lemak kakao tersimpan di dalamnya. Sel-sel tersebut kemudian pecah karena tekanan, kemudian senyawa lemak keluar dan bebas. Sifat lemak kakao yang licin menyebabkan keping biji, pasta kasar dan pasta halus yang semula padat dan kental menjadi bahan yang padat dan remah serta menyebabkan pasta kakao yang semula kental menjadi encer. Komponen utama pasta kakao secara umum terdiri atas senyawa lemak dan partikel non lemak. Senyawa lemak memiliki titik leleh yang relatif rendah, $31-35^{\circ} \mathrm{C}$ dan juga memiliki sifat alir yang baik, sebaliknya partikel non lemak memiliki sifat kesat dan sedikit agak keras (Mulato et al, 2004).

Menurut Yusianto et al (1995) dan Santoso (2014), selama proses fermentasi terjadi peningkatan kadar lemak relatif dan penurunan komponen bukan lemak pada keping biji kakao. Hal ini disebabkan oleh komponen tersebut larut di dalam air dan terurai menjadi komponen-komponen lain yang lebih kecil, sehingga dapat terdifusi keluar dari keping biji. Kadar lemak dapat meningkat $1 \%$ dan kadar komponen bukan lemak dapat menurun $1 \%$ pada 2 hari pertama fermentasi. Setelah 2-4 hari fermentasi, kadar lemak biji dapat meningkat $2 \%$ dan kadar komponen bukan lemak dapat menurun $2 \%$. Ukuran biji kakao sangat menentukan rendemen lemak. Makin besar ukuran biji kakao, makin tinggi rendemen lemak dalam biji. Kisaran kadar lemak dalam biji kakao Indonesia adalah antara 49-52\% (Wahyudi et al., 2013).

Beckett (2008), menyatakan bahwa kakao bubuk yang baik harus mengandung lemak sebesar 10-22\%. Badan Standarisasi Nasional (BSN) dalam SNI 3747:2009 mensyaratkan kandungan lemak minimal $10 \%$. Saat ini dikenal tiga jenis kakao bubuk, yaitu kadar lemak rendah (10-12\%), medium (12-17\%) dan tinggi (17-22\%) (Mulato et al, 2005). Kakao bubuk dalam penelitian ini termasuk pada kadar lemak medium $(11,32-14,82 \%)$ dan kakao bubuk netral yang umumnya berwarna coklat muda atau coklat dan biasanya digunakan untuk bahan baku industri roti atau kue. 


\section{Cemaran Logam}

Hasil analisa cemaran logam dan cemaran mikroba kakao bubuk semua perlakuan menunjukkan hasil masih di bawah syarat mutu kakao bubuk SNI 3747:2009. Grafik hasil uji cemaran logam kakao bubuk dapat dilihat pada Gambar 5. Cemaran logam timah tertinggi dibanding cemaran logam lainnya tetapi hasil ini masih dibawah ambang batas (maksimal 40). Adanya cemaran logam pada kakao bubuk dapat berasal dari kontaminasi tanah tempat tumbuh pohon kakao yang masuk ke dalam biji buah kakao (bahan baku) serta dari alat-alat proses pengolahan biji menjadi bubuk cokelat.

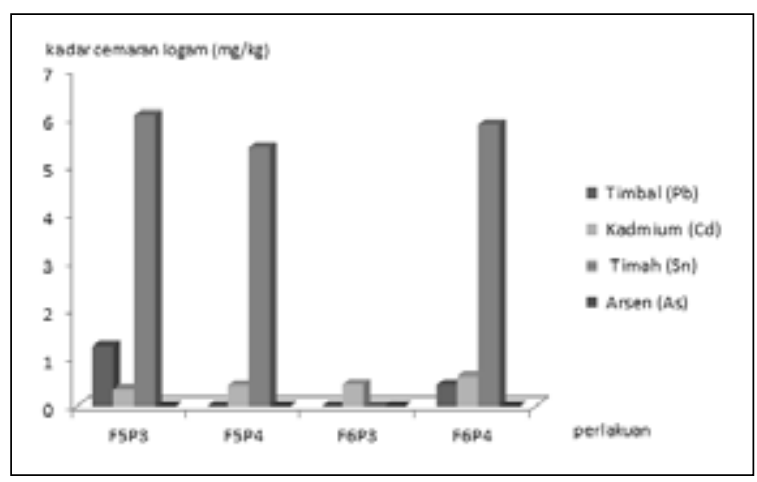

Gambar 5. Grafik hasil uji cemaran logam pada kakao bubuk

\section{Cemaran Mikroba}

Hasil analisa cemaran mikroba kakao bubuk semua perlakuan menunjukkan hasil masih di bawah syarat mutu kakao bubuk SNI 3747: 2009 seperti terlihat pada Tabel 2. Hasil uji parameter Coliform kakao bubuk semua memenuhi syarat SNI 3747-2009 yaitu < 3 APM/ gr (BSN, 2009). Golongan coliform mempunyai spesies dengan habitat dalam saluran pencernaan dan non saluran pencernaan seperti tanah dan air. Yang termasuk golongan coliform adalah Escherichia coli, dan spesies dari Citrobacter, Enterobacter, Klebsiella dan Serratia (BPOM, 2008).

Hasil uji untuk parameter Salmonella ternyata kakao bubuk masih memenuhi syarat SNI karena hasilnya semua negatif/ 25 gr sesuai standar. Adanya kandungan lemak/ lipid yang tinggi dan kadar air yang rendah dari kakao bubuk meningkatkan pertahanan dari Salmonella tetapi tidak mencegah pertumbuhannya. Proses pemanenan, fermentasi dan pengeringan (penjemuran) dapat mengkontaminasi biji kakao karena adanya berbagai varietas mikroflora, bisa juga oleh Salmonella spp (Nascimento et al, 2010). Penelitian lebih lanjut menyatakan bahwa Salmonella tidak mempengaruhi pertumbuhan kelompok mikroorganisme utama yang berperan dalam fermentasi kakao, di sisi lain pathogen dipengaruhi oleh yeast, bakteri asam laktat dan $\mathrm{pH}$ (Nascimento et al., 2013).

Tabel 1. Hasil Uji Cemaran Mikroba Kakao bubuk Sesuai SNI 3747:2009

\begin{tabular}{|c|c|c|c|c|c|c|}
\hline \multirow[b]{2}{*}{ Parameter } & \multirow[b]{2}{*}{ Satuan } & \multirow{2}{*}{$\begin{array}{l}\text { Syarat Mutu } \\
\text { Kakao Bubuk }\end{array}$} & \multicolumn{4}{|c|}{ Perlakuan } \\
\hline & & & F5P3 & F5P4 & F6P3 & F6P4 \\
\hline \multicolumn{7}{|l|}{$\begin{array}{l}\text { Cemaran mikroba: } \\
\text { a. Angka Lempeng }\end{array}$} \\
\hline Total (ALT) & Koloni/g & Maks. $5 \times 10^{3}$ & $1,9 \times 10^{2}$ & $3,8 \times 10^{2}$ & $3,7 \times 10^{2}$ & $<10$ \\
\hline b. Bakteri Bentuk Coli & APM/g & $<3$ & $<3$ & $<3,0$ & $<3,0$ & $<3,0$ \\
\hline c. Escherichia coli & Per g & Negatif & Negatif & Negatif & Negatif & Negatif \\
\hline d. Salmonella & Per $25 \mathrm{~g}$ & Negatif & Negatif & Negatif & Negatif & Negatif \\
\hline e. Kapang & Koloni/g & Maks. 50 & $<10$ & $<10$ & $<10$ & $<10$ \\
\hline f. Khamir & Koloni/g & Maks. 50 & $<10$ & $<10$ & $<10$ & $<10$ \\
\hline
\end{tabular}

\section{SIMPULAN}

Secara umum mutu kakao bubuk fermentasi hasil penelitian sudah memenuhi standar mutu kakao bubuk SNI 3747:2009.
Kadar air kakao bubuk sesuai standar maksimum $5,0 \%$ yaitu antara $3,69-4,3 \%$. Semakin lama waktu fermentasi dan banyaknya proses pengepresan pasta 
kakao mempengaruhi kadar air bubuk yang dihasilkan, sedangkan semakin banyak perlakuan pengepresan dapat mengurangi kadar lemak yang terdapat dalam kakao bubuk. Kadar lemak yang dihasilkan berkisar antara 11,32-14,82\%.

\section{DAFTAR PUSTAKA}

1. Abraham, C.S., 1982. Manufacture of Chocolate. The Planters; 58(657); 256-259.

2. Ariyanti, M., 2017. Pengaruh Pengepresan Berulang Terhadap Kadar Lemak Kakao Bubuk. Jurnal Rekayasa dan Teknologi Industri. Vol. 7 Desember. Balai Besar Industri Hasil Perkebunan Makassar.

3. Beckett, S.T. 2008. The Science of Chocolate. 2nd Edition. The Royal Society of Chemistry, Thomas Graham House, Science Park, Cambridge, United Kingdom.

4. BSN, 2009. Standar Nasional Indonesia Kakao bubuk. SNI 3747:2009. Badan Standarisasi Nasional.

5. Ginting, S. 2011. Mempelajari Pengaruh Lama Fermentasi dan Lama Penyangraian Terhadap Mutu Kakao bubuk. STEVIA Vol. 1 No.01, Hal. 6-11.

6. Mulato, S. dan S. Widyotomo, 2003. Teknik Budidaya dan Pengolahan Hasil Tanaman Kakao. Pusat Penelitian Kopi dan Kakao Indonesia. Jember.

7. Mulato, S., Widyotomo, S., dan Nur'aini H. 2004. Kinerja Alat Penghalus Pasta Cokelat Tipe Silinder Berputar. Pelita Perkebunan 20, 37-53.

8. Mulato, S., Widyotomo, S., Misnawi, dan Suharyanto, E. 2005. Pengolahan Produk Primer dan Sekunder Kakao. Pusat Penelitian Kopi dan Kakao Indonesia, Jember.

9. Mulato, S., Widyotomo, S., Purwadaria, H.K. 2008. Kinerja Alat Kempa Hidrolik Sistem Terputus untuk Proses Ekstraksi Lemak Kakao. Pelita Perkebunan, 24 (1), Hal. 62-79.

10. Nascimento, M. D. S., da silva, N., da Silva, I. F. S., Marques, de C. da
E. R., dan Santos, A. R. B. 2010. Enteropathogens in Cocoa PreProcessing. Food Control, 21(4), 408-411.

11. Nascimento, M. D. S., Pena, P. O., Brum, D. M., Imazaki, F. T., Tucci, M. L. S., dan Efraim, P. 2013. Behavior of Salmonella During Fermentation, Drying and Storage of Cocoa Beans. International Journal of Food Microbiology, 167(3), 363-368. http://doi.org/10.1016/j.ijfoodmicro. 2013.10.003.

12. Nasution, Z., M.C. Wahyudi dan S.L. Betty, 1985. Pengolahan Coklat. Agroindustri. IPB-Press, Bogor.

13. Santoso, Y.P. 2014. Perubahan Kadar Lemak dan Aktivitas Antioksidan Selama Proses Fermentasi Spontan pada Biji kakao (Theobroma cacao L.). Skripsi. Fakultas Teknologi Pertanian, Universitas Katolik Soegijapranata, Semarang.

14. Towaha, J; Anggraini, D.A; Rubiyo. 2012. Keragaan Mutu Biji Kakao dan Produk Turunannya Pada Berbagai Tingkat Fermentasi: Studi kasus di Tabanan, Bali. Pelita Perkebunan Vol. 28 No. 3. 166-183

15. Venter, M.J., Kuipers, N.J.M, de Haan, A.B. 2007. Modelling and Experimental Evaluation of High Pressure Expression of Cocoa Nibs. Journal of Food Engineering 80, 1157-1170.

16. Wahyudi, T.T.R, Panggabean, dan Pujiyanto. 2013. Kakao, Manajemen Agribisnis dari Hulu ke Hilir. Penebar Swadaya.

17. Yusianto, Wahyudi, T, dan Sumartono, B. 1995. Pola Citarasa Biji Kakao Dari Beberapa Perlakuan Fermentasi. Pelita Perkebunan, 11, 117-131.

18. Yusianto, Winarno, H. dan Wahyudi, T. 1997. Mutu dan Pola Cita Rasa Biji Beberapa Klon Kakao Lindak. Pelita Perkebunan, 13, 171-187. 